\title{
Mîtrâ Elyâtî'den Bir Küçürek Öykü Örneği: Karanlıkta Kalıyoruz
}

\section{Aysel YILDIZ EROL*}

\begin{abstract}
ÖZ
Küçürek öyküye temel olan ve günümüzde yaygın olarak öykü terimiyle karşılanan hikâyenin, özellikle modern duyarlılıklar ve modernist yaklaşımlar sonucunda çok değişik örnekleri üretilmiştir. En yaygın örneği ise kısa öykü olarak adlandırılan metinlerdir. 20. yüzyılın son çeyreğinden itibaren daha çok ön plana çıkan minimal öykü, Bat1 edebiyatında; short short story, flash fiction, sudden fiction; Türk edebiyatında; küçürek öykü, çok kısa öykü, kısa kısa öykü; Fars Edebiyatında ise; dâstânek, dâstân-i kûtâh-i kûtâh ve dâstân-i heylî kûtâh olarak isimlendirilmektedir. Küçürek öyküler bütün bir hikâyenin aksine sadece bir sahne ya da bir kişi üzerine odaklanan kısa öykülerdir. Karakter tahlili, olayın geçtiği mekân tasviri, betimlemeler en aza indirgendiğinden okuyucuya yorumlama ve farklı aç1lardan yaklaşım imkânı tanınmaktadır. Çalışmamızın temel örneklemini Fars Edebiyatından seçtik, bu yüzden küçürek öykü tanımı için Farsça literatüre baktığımızda; "dâstânek, dâstân-i kûtâh-i kûtâh ve dâstân-i heylî kûtâh” gibi birkaç farklı terim ile karşımıza çıkmaktadır. Hikâye edebiyatı terimi olan dâstânî kûtâhî kûtâh'ın akılda kalan en önemli özelliği son derece kısa (500 ila 1500 kelime) olmasıdır. Farsçada dâstânek olarak adlandırılan küçürek öykü olayları ve durumları yorumlayan öykünün aksine uzunluktan yoksundur, sadece olaylardan ve durumlardan bahseden bir niteliktedir. Genellikle bir sahne ya da bir kişi üzerine yoğunlaşır ve bunlar üzerinde tahlilde bulunur. Hareketli olan öykünün aksine daha durgundur.
\end{abstract}

Arş. Gör. Karamanoğlu Mehmetbey Üniversitesi, Yabancı Diller Yüksekokulu, Mütercim ve Tercümanlık Bölümü, Farsça Mütercim ve Tercümanlık A.B.D., Karaman/Türkiye E-posta: ayselyildiz@kmu.edu.tr, ORCID: 0000-0002-5043-5753,DOI: 10.32704/erdem.838801 Makale Gönderim Tarihi: 05.07.2019 * Makale Kabul Tarihi: 15.05.2020 * (Sanat ve Edebiyat Mk.) 
$\mathrm{Bu}$ çalı̧̧mada, öykünün Farsçası ve Türkçe çevirisi verildikten sonra, 1950 Tahran doğumlu olan Mîtrâ Elyâtî̀nin hayatı hakkında kısa bir bilgi verilecek, sonrasında küçürek öykünün Fars ve Türk Edebiyatındaki yerinden bahsedilecektir. Mîtrâ Elyâtînnin 2001 yılında Gulşîrî Vakfi ve Öykü Evi ödüllerini alan Matmazel Keti adlı kitabının en etkileyici ve dikkat çekici öyküsü olarak gösterilen Karanlıta Kahyoruz öyküsünün, yapısal ve tematik açıdan tahlili yapılacaktır. Öykü, bir anne, çocuğu, yeni kocası ve hikâye anlatıcısı olan ölmüş eski koca arasında geçmektedir. Yaşanan diyaloglarda anlaşılmaktadır ki çocuk, annesi ve pek de hoşlanmadığı üvey babası ile yaşamaktadır. Bu sırada anlatııının bir fotoğraf çerçevesinden okuyucuya seslendiği dikkatimizi çekmektedir. "Karanlıkta Kalıyoruz" küçürek öyküsü, geçmiş ile bugünün, hayal ile gerçekliğin iç içe geçmesiyle oluşan bir öyküdür. Hikâyenin okuyucuda gerçeklik izlenimini uyandırması, ayrıntıların objektif olarak tasvir edilmesinden kaynaklanmaktadır. Bu nedenle de okuyucu; hikâyeye karşı oluşan, duygu yoğunluğunu, merak ve heyecanı hiç kaybetmiyor.

Anahtar Kelimeler: Kısa öykü, küçürek öykü, dâstânek, Mîtrâ Elyâtî, Karanlikta Kaliyoruz. 


\title{
Example of A Küçürek Story From Mîtrâ Elyâtî: We Stay in the Dark
}

\begin{abstract}
Story, which is the basis of the minimal story and is widely regarded as story, has produced many different examples, especially as a result of modern sensibilities and modernist approaches. The most common example is short stories. Minimal story which is more prominent, since the last quarter of the 20th century, it is named in the Western literature as, short story, flash fiction, sudden fiction; in Turkish literature; küçürek story, very short story, short short story; in Persian literature; dâstânek, dâstân-i kûtâh-i kûtâh ve dâstân-i heylî kûtâh. Küçürek stories are devoid of length and, unlike the story focus on a scene or a person. Since the character analysis, the description of the place where the event takes place, the descriptions are minimized, the reader is given the opportunity to interpret and approach from different angles. We chose the main sample of our study from Persian Literature, so when we look at the Persian literature for a short story definition; It appears with several different terms such as "dastânek, dastân-i kûtâh-i kûtâh and dastân-i heylî kûtâh". The most important feature of dastânî kûtâhî kûtâh, which is the term story literature, is that it is extremely short (500 to 1500 words). Unlike the story that interprets events and situations, the short story, which is called dastânek in Persian, lacks length, it only talks about events and situations. Usually he concentrates on and analyzes a scene or a person. Unlike the moving story, it is more static.
\end{abstract}

In this study, after giving the Persian version and its translation, a brief information about Mitra Elyati's life who was born in 1950 in Tehran, will be given, and then the place of küçürek story both in Turkish and Persian Literature will be mentioned. We will analyze, We Stay in the Dark, which is shown as one of the most impressive and remarkable short stories of Mitra Elyati's Mademoiselle Cathy, which is also has won Golshiri and Khaneh Dastan prices in 2001, in structural and thematic way. The story takes place between a mother, her child, her new husband and a dead old husband who is a storyteller. It is understood in the dialogues that the child lives with his mother and stepfather whom he does not like very much. In the meantime, we notice that the narrator addresses the reader from a photo frame. We Stay in the Dark, is a story formed by the intertwining of past and present, dream and reality. The fact that the story evokes the impression of reality in the reader stems from the objective description of the details. Therefore, the reader; He never loses the intensity of emotion, curiosity and excitement that arises against the story.

Keywords: Short story, küçürek story, dâstânek, Mitra Elyati, We Stay in the Dark. 


\section{Mîtrâ Elyâtî}

$\dot{\mathbf{I}}$ ranlı yazar ve şair Mîtrâ Elyâtî, 1950 yılında Tahran'da doğmuştur. 1976 y1lında şiir hayatına ve 1997 yılından itibaren de yazarlık hayatına başlamış, hikâyeleri çeşitli prestijli dergilerde yayınlanmıştır. Yazarın, çalışmamıza temel olan "Karanlıkta Kalıyoruz" adlı öyküsü, Çeşme Yayınları tarafından 6. baskısı yapılan ve yedi öyküden oluşan Matmazel Keti adlı kitabın altıncı öyküsüdür. Yazarın bu kitabı 2001 yılında Gulşîrî Vakfi ve Öykü Evi - Hुâne-yi Dâstân - ödüllerini almı̧̧tır (Mahmûdî, 2016: 365). Elyâtî̀nin diğer eserleri; Şemidânîhâ ve Kâfe-yi Perî Deryâyî̉dir.

\section{Küçürek Öykü / Dâstânek}

Küçürek öyküye temel olan ve günümüzde yaygın olarak öykü terimiyle karşılanan hikâyenin, özellikle modern duyarlilıklar ve modernist yaklaşımlar sonucunda çok değişik örnekleri üretilmiştir. En yaygın örnek ise kısa öykü olarak adlandırılan metinlerdir. H. E. Bates; kısa öykü için sağlam bir sınamadan geçmelidir der ve gereksiz bir tümcenin, hatta tek bir gereksiz sözcüğün bile, kısa öykünün dengesini bozabileceğini belirtir (2001: 184). Erden, kısa öykünün; durağan, parçalanmış, şekilsiz ve yalnızca bir karakter taslağ1 olduğunu ve geçici tek bir anın anlatımı olduğunu belirtir (2002: 33).

Farsça sözlük anlamına baktığımızda hikâye; birbiriyle ilişkili birkaç olay içeren ve sözdizimsel olarak süreklilik zamanı belirten mensur metinlere denmektedir. Roman, kısa hikâye, çok kısa hikâye ve uzun hikâye gibi hikâye çeşitleri vardır (Şerîfî 2013: 611). Bir başka tanım ise hikâyenin hayali ya da gerçek bir olaya dayanarak yazılan edebi mensur eser olduğu şeklindedir (Enverî 2015: 980).

Şaban Sağlık küçürek öykünün birdenbire ortaya çıkan bir edebiyat türü olmadığını, küçürek öykünün öncesinde kısa öykü olarak adlandırılan bir geçiş sürecinin söz konusu olduğunu belirtir (2014: 288). Kısa öyküler dar alanda sıkıştırılmış, az sayıda sözcükle yoğun anlamlar aktarma gücüne sahip olan sanatsal iletişim araçlarıdır. Kısa öykünün üç önemli belirleyici özelliği vardır; kısalık, yoğunluk ve birlik (Erden 2002: 314). Yaşanan süreç içinde kısa öykü terimi de yeterli görülmemiş olmalı ki, daha sonraları kısa kısa öykü adı verilen daha başka öykü örnekleri de gündeme gelmiştir (Sağllk 2014: 257). Necip Tosun küçürek öykü ile ilgili olan iki tartısma konusunu şu şekilde belirtir:

Öykü ve minimalizm bağlamında ilk tartışma, adlandırma konusunda yaşanmakta; bu anlayışın örnekleri, mini öykü, minimal öykü, kısa kısa öykü, ani öykü, çok kısa öykü, mikro kurmaca, kü- 
çük öykü, küçürek öykü (...), adlarıyla tanımlanmaya çalışılmaktadır. Ne var ki henüz herkesin benimsediği ortak bir ada kavuşmuş değil. İkinci tartışma da bağımsız yazınsal bir tür mü yoksa öykünün bir türevi mi olduğu konusunda yaşanmakta (2007: 86).

Minimalist öykü ya da küçük ölçekli kurmaca olarak da adlandırılabilecek çok kısa öyküler insan yaşamlarından dondurulmuş kısa anlar, yaşanmı̧ kısa olaylar, anekdotlar, kurulan düşlerden birisi, bir monolog, bir içsel konuşma ya da bir episod olarak okuyucunun karşısına çıkmaktadır (Erden, 2002: 315). Ahmet Buran, makalesinde küçürek öykü kavramının ortaya çıkış sürecini şu şekilde aktarır: Ramazan Korkmaz’ın Türkiye'de çok fazla yaygınlaşmamış olan bu anlatı türüne, Batı'da "short short story, flash fiction, sudden fiction", Türkçede ise "kısa, çok kısa öykü" dendiğini ancak başka bir tabirin daha uygun olacağını savunduğunu belirtir. Buran'da bu düşünceye karş111k, yap1sını açıklayarak "küçürek öykü" terimini önermiştir. Bunun üzerine Ramazan Korkmaz bundan sonraki çalı̧̧malarında ve öğrencilerine yaptıracağ çalışmalarda bu terimi kullanmıştır (Buran, 2012: 24). Küçürek öykü teriminin ortaya çıkış serüveni bu şekilde aktarılır. Necip Tosun da küçürek öykünün ortaya çıkı̧̧ı için pek çok faktör olduğunu, resimde, müzikte, mimaride ve sinemada mevcut olan minimal yaklaşımın son yıllarda öyküde de karşılık bulduğunu ifade etmiştir (2007: 86).

Farsça literatüre baktığımızda küçürek öykü için; "dâstânek, dâstân-i kûtâh-i kûtâh ve dâstân-i heylî kûtâh” gibi birkaç farklı terim ile karşımıza çıkmaktadır. Hikâye edebiyatı terimi olan dâstânî kûtâhî kûtâh'ın akılda kalan en önemli özelliği son derece kısa (500 ila 1500 kelime) olmasıdır (Şerîfî 2013: 614). Farsçada dâstânek olarak adlandırılan küçürek öykü olayları ve durumları yorumlayan öykünün aksine uzunluktan yoksundur, sadece olaylardan ve durumlardan bahseden bir niteliktedir. Genellikle bir sahne ya da bir kişi üzerine yoğunlaşır ve bunlar üzerinde tahlilde bulunur. Hareketli olan öykünün aksine daha durgundur (Rûzbeh 2003: 29-30). Dâstânek türünün belli başl1 özellikleri için şu maddeler söylenebilir:

- Basit ve anlaşılır bir planının olması,

- Zaman ve mekânda sinırlılığın,

- Şimdiki zamanda bir anlatım olması,

- Karışı olay örgüsüne sahip olmaması,

- Açıklama ve uzun anlatımdan uzak olması,

- Genellikle diyaloglardan oluşması (Ġiyâŝ̂i 2014: 13). 
Korkmaz'a göre 20. yüzyılın son çeyreğine yakın bir zamandan itibaren yoğun bir şekilde öne çıkan küçürek öykü de aslında Filozof Beydaba, Ezop, Şeyh Sadi ve Mevlânâdan beri hep var olagelen bir anlatı türüdür (2017: 17). Farsçada ise küçürek öykü (dâstânek) türünde modern anlamda Sâdık Çûbek'in "Adalet" ve İbrahim-i Gülistân'ın "Balık ve Eşi” eserleri akla gelen ilk örneklerdendir.

$$
\text { مى مانيم توى تاريكى1 }
$$

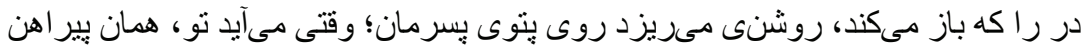

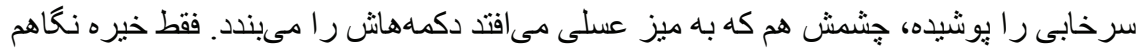

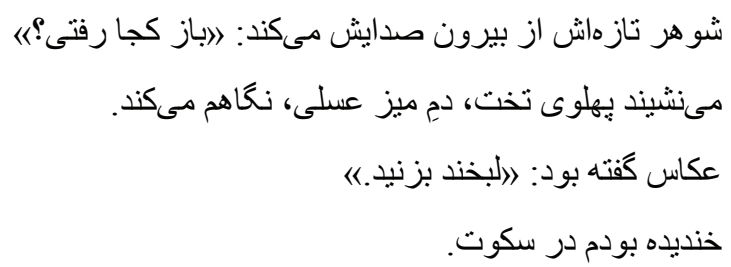

مىجرخاندم رو به ديو ار، جورى كه شايد نبينمش.

$$
\begin{aligned}
& \text { جشمم مى افتد به نقانشى بِسرمان روى ديو ار. } \\
& \text { رنح آب را خاكسترى كرده. كفته بودم: 》آبى بايد باثنها }
\end{aligned}
$$

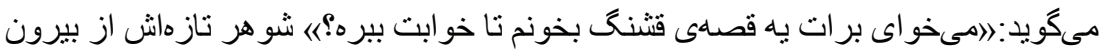

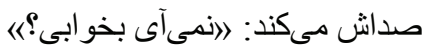
كتاب را كه بر ميدارد، مىافتم زمين.

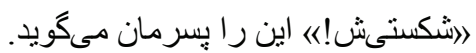
برم مىدارد. نكاهم مىكند. مىخندم.

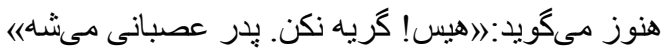

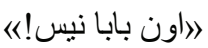
بر مىگردد. نحاهم مىكند. افتادهام روى بالش. مىخندم هنوز.

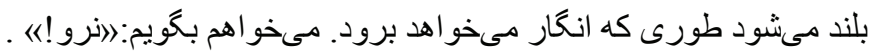

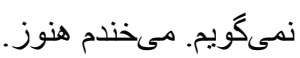

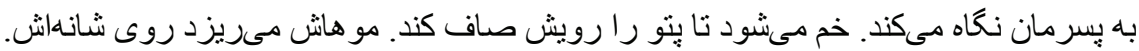

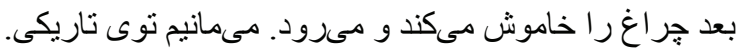

$\overline{1}$ Mîtrâ Elyâtî, Mâdmâzel Ketî (ve Çend Dâstân-i Dîger), Çeşme, Tahran, 1395 hş. 


\section{KARANLIKTA KALIYORUZ ${ }^{2}$}

Kapı açılınca oğlumuzun battaniyesine bir aydınlık sızdı. Yine fuşya gömleğini giydiğini o içeri girince fark ettim, gözü sehpaya iliştiğinde düğmelerini ilikledi. Gözlerini dikmiş, sadece bana bakıyordu.

O anda, yeni kocası dişarıdan ona seslendi "Yine nereye gittin?"

Yatağın kenarına, sehpanın dibine oturdu. Bana baktı.

O zaman fotoğrafçı “Gülümseyin!” demişti.

Bende sessizce gülümsemiştim.

Onu görmeyeceğim bir şekilde yüzümü duvara çevirdi.

$\mathrm{O}$ anda gözüm oğlumun duvardaki resmine takıldı.

Suyun rengini gri yapmış. Oysa ona “Mavi olmalı!” demiştim.

Oğlumuza, "Uykun gelene kadar sana güzel bir hikâye okumamı ister misin?” diye sorduğu esnada, yeni kocası yine ona "Uyumaya gelmiyor musun?" diye seslendi.

O, hikâye kitabını sehpadan alırken beni yere düşürdü.

Oğlumuz, “Onu kırdın anne!” dedi o anda.

Beni yerden aldı, bana baktı. Ben hala gülümsüyordum.

“Şşşt! Ağlama! Baban sinirlenir." dedi oğlumuza.

Oğlum, "O babam diill" dedi.

Döndü, bana baktı. Yastığa düşmüştüm. Hala gülümsüyordum.

Kalktı, odadan gitmek ister gibi bir hali vardı. "Gitme!" demek isterdim.

Diyemedim. Hala gülümsüyordum.

Oğlumuza baktı, battaniyesini düzeltmek için eğildi. O an saçları omuzlarına döküldü. Sonra lambayı söndürüp odadan çıktı ve biz yine her zamanki gibi karanlıkta kalıyoruz.

\section{“Karanlıkta Kalıyoruz” Küçürek Öyküsünün Tahlili}

Mîtrâ Elyâtî’nin küçürek öyküye Farsça örnek olarak gösterdiğimiz "Karanlıkta Kalıyoruz" hikâyesi; genç bir kadının, oğlunun odasına girmesi ile

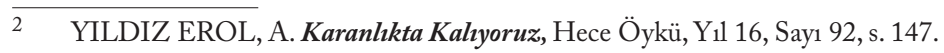


başlamaktadır. Kadın ilk başta, eski kocasına (hikâye anlatıcısı) ait fotoğrafın bulunduğu çerçevenin karşısında konumlanmıştır. O sırada yeni kocası dışarından yanına gelmesi için kadına seslenir. Eski kocası fotoğrafın çekildiği o anı hatırlar. Kadın eski kocasının fotoğrafını duvara doğru çevirir ve o esnada eski kocası duvarda asılı olan, oğlunun çizmiş olduğu resmi görür. Oğlu resimde suyun rengini griye boyamıştır, oysa ona, suyun renginin mavi olmasını söylediğini hatırlar. Annesi oğluna hikâye okumayı teklif eder. Sehpadan kitabı alırken çerçeveyi yere düşürür, oğlu bu duruma üzülür ve annesine "çerçeveyi kırdın" diye hayıflanır. Annesi oğluna ağlamamasını (üvey) babasının kızacağını söyler, çocuk ise onu babası olarak kabul etmediğini belirtir. Kadın oğlunun battaniyesini düzeltir, 1̧̧ı̆̆ı kapatır ve odadan çıkar. Oda ve içindekiler yine karanlıkta kalır. Öykü bu şekilde son bulmaktadır.

"Karanlıkta Kalıyoruz" küçürek öyküsüne baktığımızda dikkatimizi çeken birçok nokta vardır: bunlardan biri; kadının ikinci evliliği yapması ve bu konuyla ilgili, özellikle ilk evlilikten doğma bir çocuk olunca yaşanan sıkıntılardır. Çünkü öyküde üvey babanın, çocuğun varlığından rahatsız olduğu okuyucuya yansitılmaktadır, bunu da annenin çocuğa kullandığı şu cümleden anlıyoruz. "Şşşt! Ağlama! Baban sinirlenir.” Ayrıca öykünün çocuk kahramanının da, annesinin yeni kocasını kabul etmediğini, “O babam diil!” (Elyâtî 2002: 68) ifadesinde aç1kça görüyoruz.

"Karanlıkta Kalıyoruz" öyküsünde anlatıcının kim olduğuna dair açık bir ifade yoktur ancak İran'a bakarak kadının ikinci kez evlenip, oğlunun odasında eski eşine dair fotoğrafın bulunması bize anlatıcının ölmüş olduğu hissini vermektedir, anlatıcının neden ve ne zaman öldüğü bildirilmiyor. Hikâyenin ölmüş bir babanın fotoğraf çerçevesinden okuyucuya aktarılması akıllara Shakespeare'in Hamlet oyununu getirmektedir ('Alî Necafî 2009).

İsmail Çetişli’nin, Maupassant (olay öyküsü) tarzı öykü ile Çehov (durum öyküsü) tarzı öykü üzerine belirlediği genel özellikleri ve farklılıklarına baktığımızda Elyâtînin bu küçürek öyküsü Çehov tarzı öykü sınıfındadır (2009: 196). “Karanlıkta Kalıyoruz" öyküsü durum öyküsü olduğundan kişilerinin özenle seçilmesi pek söz konusu değildir. Bu kahramanlar herhangi bir ayrıcalıkları olmayan, anne, çocuk, baba, üvey baba gibi her zaman çevremizde görebileceğimiz sıradan insanlardır.

"Karanlıkta Kalıyoruz", genellikle anlatıcı durumunda olan ve hikâyede ölmüş ve fotoğraf çerçevesi içinden okuyucu ile buluşan koca, kocasını kaybettiği için ikinci bir evlilik yapmış olan kadın, evde üvey baba ve annesi ile 
yaşayan bir çocuk ve son olarak kadın kahramanın yeni kocası olmak üzere dört karakter üzerinden anlatılmıştır.

Küçürek öykülerin genel özelliklerinden biri de giriş ve gelişme bölümünün açık bir şekilde gösterilmemesidir. Küçürek öyküler için Ramazan Kokmaz, yazarın sıradan ama yoğun ve özgün yaşantıları daha çok simgesel düzeyde okura aktardığını söylemektedir (2003: 25). Küçürek öykülerde ayrıntılar değil, asıl sonuç hedeflenir. Anlam, son paragraf, son cümle, son satırda yer alan kelimeye yüklenir ki okur bir şok geçirerek kelimeleri anlamsal yönden tetkike çalışsın; ancak, hemen ifade etmek gerekir ki bazen okurda şok etkisi yapılan yer küçürek öykünün ilk kelimesi, ilk cümlesi veya ilk satırı da olabilir. Bu şekliyle küçürek öyküler, durum öyküsü özelliği taşımış olur. Zira küçürek öyküler, anlık bir oluşun, fark edişin ve isyan edişin çığlıdır (Korkmaz ve Deveci 2011: 28). Elyâtî de bu eserinde ölmüş bir babanın, hayal ile gerçek karışımı hikâyesini simgesel düzeyde okurlara aktarmaktadır. Olay örgüsüne baktığımızda öncelikli olarak ortadan başlatma sistemi ile hikâyeye başlanmış ve akabinde geriye dönüş tekniği ile eskide olmuş olaylar aktarılarak devam etmiş ve son olarak sonuç verilmiştir.

"Karanlıkta Kalıyoruz" adlı küçürek öykü örneğimizde zaman ve mekân kavramları net olarak belirtilmemiş ve bu kavramlar okuyucuya sadece genel bir kanı olarak hissettirilmiştir. Hikâyede kullanılan simgeler; örneğin hikâyenin tam olarak yaz ayında geçmediğini düşündüren battaniye ve bir gece vakti geçtiğini düşündüren lamba, okuyucuya zaman kavramı açısından genel bir kanı vermektedir. Yine aynı şekilde hikâyenin geçtiği mekân olan çocuk odası, detaylıca tasvir edilmemiştir. Okuyucuya hikâye ile birlikte, odada sehpa, duvarda bir resim ve yatağın olduğu aktarılır. Tüm bunlardan hareketle anlatıcının zaman ve mekân üzerinde özellikle durmadığını söylememiz yerinde olacaktır.

Kurgusal metinlerde üç ayrı zaman kavramından söz edilmekte; nesnel zaman, vaka zamanı ve anlatma zamanı. Anlatma zamanını da iki biçimde inceleyen Çetin'e göre anında aktarma ile romanda geçen olaylar daha olup bitmekteyken, sıcağı sıcağına aktarılmaktadır (2009: 131). Bu tanımı öykünün giriş cümlesinde görmekteyiz: "Kapı açılınca oğlumuzun battaniyesine bir aydınlık sızdı. Yine fuşya gömleğini giydiğini o içeri girince fark ettim, düğmelerini iliklerken gözü sehpaya ilişti. Gözlerini dikmiş, sadece bana bakıyordu."

Mehmet Tekin'in Roman Sanatı kitabında; geçerli olan zaman şimdidir her şey bu şimdinin içinde kurgulanır ancak romanı roman yapan, bu değildir. Romanc1, gerçek olan şimdiden geçmişe ve hatta geleceğe uzanır (...) demiştir (Tekin 2002: 233). Romanda yer alan her şeyin insanın, çevrenin, zamanın, eşya ve düşüncenin bir mazisi vardır. Romancı bu elemanlara ruh ve can ver- 
mek için firsat buldukça geçmişe döner. $\mathrm{O}$ bu işlemi gerçekleştirirken geriye dönüş tekniğinden yararlanır (Tekin 2002: 233-234). Örnek hikâyemizde de odada, sehpa üzerinde durmakta olan anlatıcı konumundaki çerçevenin içindeki fotoğrafin mazisi "fotoğrafçı gülümseyin demişti" ifadesi ile okuyucuya kapalı bir şekilde verilmeye çalışılmıştır.

Çetin'e göre "Karanlıkta Kalıyoruz" öyküsü, anında aktarma ile yazılmaya başlanmış ancak yer yer hali hazır ve geçmiş zaman karışımı ile devam etmiştir. Kısacası; Elyâtî öyküsünde olayların anlatımı için kronolojik bir sıra kullanmamıştır. Anlatıcı bir gece vakti geçen anlık bir durumu anlatırken, okuyucuyu aydınlatmak üzere yukarıda da yer verdiğimiz üzere geriye dönüş tekniğine başvurarak fotoğrafin çekildiği zamana döner ve bunu da okuyucuya; o zaman fotoğrafçı "gülümseyin" demişti, ifadesi ile yansıtır. Bir başka örnek ise; anlatıcı oğlu ile daha önce de resim yaptıklarını ve oğluna gerçekte suyun rengine dair bilgi verdiğini belirtmek amacılla oysa ona "mavi olmalı" demistim, cümlesi ile geriye dönüş tekniğine başvurur (Elyâtî 2002: 67). Bu şekilde birdenbire geçmişe dönüşlere yer veren anlatıcı şimdi ile geçmişin anlatımı arasındaki geçişlerde okuyucuya herhangi bir açıklama yapmaz. Bu teknik okurun merak duygusunu kamçıladığı gibi, klasik öyküleme tarzını yerinden oynatıp öyküye bir dinamiklik katmaktadır (Özata Dirilikyapan 2010: 160).

Yirmi dört satırdan oluşan bu küçürek öyküde dikkatimizi çeken bir diğer teknik ise leitmotif kullanımıdır. Nurullah Çetin, Roman Çözümleme Yöntemi kitabında leitmotifi, ana düşünceyi ya da yan iletileri yansıtmak üzere tekrar edilen simgesel değerdeki kelime, ifade, cümle, mısra gibi dil unsurlarıdır şeklinde tanımlamıştır (2004: 125).

"Karanlıkta Kalıyoruz" hikâyesinde beş kez tekrar edilerek leitmotif oluşturan "gülümseme" sözcüğü öznenin çaresizlik, hüzün içinde olduğu hâlihazırda ve geçmişteki psikolojik durumunu okura sezdirmektedir. Ayrıca anlatıcı, hikâyenin hem adı hem de bitiş cümlesi olan "karanlıkta kalıyoruz" leitmotifi üzerinden de içinde bulunduğu hüzün ve çaresizliği okura yine güçlü bir şekilde yansitmaktadır.

Mehmet Tekin kitabında anlatıcı tiplerini üçe ayırmıştır. 1. tekil kişi (ben), 3. tekil kişi (o) ve 2. çoğul kişi (siz) (2009: 26). Elyâtî’nin minimalist öyküsünde her üç anlatıcı tipini de görmekteyiz. Yirmi dört satırdan oluşan bu öyküde 1 . tekil kişi (ben) anlatıcı tipinin sıklıkla kullanıldığını görüyoruz. Ben-anlatıcılı hikâyelerdeki yaşanmışlık, her zaman gerçek yazarla ilgili olmasa da, anlatıcının yaşamını özetleyen ya da belli yaşam kesitlerinden sahneler gösteren metinler olarak ortaya çıkarlar (Aslan 2007: 83). 
“Kapı açılınca oğlumuzun battaniyesine bir aydınlık sızdı." cümlesi ile çoğul anlatıcı ağzıyla başlayan öykü; daha sonra ben anlatıcı olarak devam eder gözlerini dikmiş, sadece bana bakıyordu (Elyâtî 2001: 67). Sonrasında ise aynı zaman diliminde, farklı mekânlarda, farklı kişilerce yaşanmış olayların hepsini görmüş, izlemiş gibi aktaran (Çetin 2009: 107), Tanrısal konumlu gözlemci anlatıcı devam eder; "o anda yeni kocası dışarıdan ona seslendi” (Elyâtî 2001: 67). Bu şekilde devam eden öykünün tamamına baktığımızda tek bir anlatıcı tipi değil üç farklı anlatıcı tipi kullanıldığını görürüz.

İnsanoğlunun varoluş sorununu ele alan küçürek öyküler, yalnızlı, bunaltı, zamansızlık, yersizlik, iletişimsizlik gibi izlekler üzerine kurulur (Eşitti 2016: 207). Öyküde kadının henüz oğlunun odasına girerken yeni kocasının onu geri çağırmasi; annenin içeriden seslenen yeni kocasına cevap vermeden, oğluna bir şeyler söylemesi; annesinin hikâye okuma teklifine cevap vermeyen çocuğun, babasının fotoğrafinı yere düşürünce annesine hayıflanması, ölmüş olan babanın çaresizce tüm olanlara tanıklı etmesi ile Mîtrâ Elyâtînnin toplamda yirmi dört satırdan oluşan küçürek öyküsünde aile içindeki iletişimsizliği görüyoruz. Ayrıca öykünün girişinde anlatıcının; "yine fuşya gömleğini giydiğini o içeri girince fark ettim", cümlesinde geçen fuşya gömlek imgesi, ki kadının ölen kocasıyla olan hayatında da aynı gömleği giymekte olduğu, bize kadının çaresizliğini, hayatın devam ettiği ve ölenle ölünmez düşüncesini hissettiriyor. Kadın belki de en büyük acısını unutup yoluna devam etmeye çalışmaktadır.

Küçürek öykünün özelliği gereği “Karanlıkta Kalıyoruz” öyküsü kısa olmasına rağmen okuyucuya farklı açılardan bakma imkânı sunmaktadır. Genel olarak baktığımızda yazar minimal öyküsünde ölmüş olan bir babanın, geride bıraktığ1 ailesine duyduğu özlem konusunu ele almıştır. Ölüm gibi soyut bir durumu, kendisinin yer aldığı bir fotoğraf çerçevesinden somutlaştırarak aktarmı̧sırı. Öykü genelinde anne şefkati, ölmüş bir babanın karısına ve çocuğuna duyduğu sevgi ve özlem, bir çocuğun babasına duyduğu bağlllık duygusu, çaresizlik ve hüzün gibi duyguların yoğun olarak işlendiğini görmekteyiz. Saflğın ve temizliğin göstergesi olarak varlık bulan çocuk karakteri Mîtrâ Elyâtînnin öyküsünde karşımıza hayal kırıklığına uğramış, yaşama sevinci elinden alınmış olarak yansitılmaktadır. Bunu da; duvardaki resimde suyun rengini babasının söylemiş olmasına rağmen mavi yerine, daha iç karartıcı, içe kapanıklık hissi veren gri renk yapmış olmasından çıkartmak mümkündür. Ayrıca üvey babasının varlığ1 konusunda okuyucuya sezdirilen asi tavırları, bize ölmüş babasına dair bir kalp kırıklı̆ğ olabileceğini de hissettirmektir. 


\section{SONUÇ}

Genel olarak bu minimal öyküye baktığımızda yazarın kapalı anlatımından kaynaklı bir anlam kargaşası bulunmaktadır ve Mîtrâ Elyâtînnin bu küçürek öyküsünde geçmiş ile bugünün, hayal ile gerçeğin iç içe geçtiğini görmekteyiz. Anlatıcı hem kendisi hem de yaşanılan durumla ilgi şeyleri okuyucusuna kapalı bir şekilde sunmaktadır. Bu nedenle de okuyucu; hikâyeye karşı oluşan, duygu yoğunluğunu, merak ve heyecanı hiç kaybetmiyor. İ̧eriden yeni kocası seslendi, öykünün girişinde gerçekleşen bu sahne hem çarpıcı hem merak uyandırıcıdır. Hikâyedeki şaşırtıcı olay örgüsü, kurmaca anlatım, anılar biçiminde aktarılan geçmişteki yaşanmışlıklar, "bikâye kitabını sehpadan alırken beni yere düşürdü", ifadesi ile ölümün simgesel anlatımı ve gerçek zaman ile kurmaca zaman arasındaki kaymalar bu kısa öyküye oldukça zor yorumlanır bir anlam boyutu katmıştır. Elyâtî yazmış olduğu minimal öykü ile okuyucusuna eşyanın insanlaştırıldığını göstermektedir. Ayrıca öykünün ana fikrini hem başlık (Karanlıkta Kalıyoruz), hem de son cümle olarak kullanılan ifadede bulmak mümkündür: (...) "Sonra lambayı söndürüp odadan çıktı ve biz yine her zamanki gibi karanlıkta kalıyoruz”. 


\section{KAYNAKLAR}

Aslan, C. (2007). Sait Faik Abasıyanı'ın Öykülerinde Kurgu ve Anlatım Teknikleri. Yayımlanmamış Doktora Tezi. Ankara Üniversitesi, Ankara.

BATES, H. E. (2001). Yazınsal Bir Tür Olarak Kısa Öykü. (çev: G. Ezber,). Buran, A. (2012). Bilim Alanlarında Terimlerin Önemi ve "Küçürek Öykü" Terimi, Turkish Studies, 7(4), 21-25. doi: 10.7827/TurkishStudies.3924

Çetişli, İ. (2009). Batı Edebiyatında Edebi Akımlar. Ankara: Akçă̆ Yayınları. Dovletîyân: (2010). Berrsî-yi Şurû'-i Dâstân der Dâstânek. Ketâb Mâb-i Edebiyyât, 32, 68-71. http://ensani.ir/file/download/ article/20120326165217-3016-421.pdf (Erişim: 12.04.2019).

Enverî, Ḥ. (2015). Ferheng-i Feşorde-i Sohen. (13. Baskı)

Erden, A. (2002). Kısa Öykü ve Dilbilimsel Eleştiri. İstanbul: Gendaş Kültür.

Giiyâsîn, Z. (2014). Sâhtâr-i Dâstânek der Berhî ez Hiikâyethâ-yi Golistân. Roşd-i Âmûzeş-i Zebân ve Edeb-i Fârsî, 105, 12-13. http://ensani.ir/file/ download/article/20130623091319-9552-131.pdf (Erişim: 12.03.2019).

Hüsrevşahi, H. (2005). İran Edebiyatı Öykü Antolojisi. İstanbul: Dünya Yayıncilik.

Kanar, M. (1998). Hikâye. Diyanet İslam Ansiklopedisi. https:// islamansiklopedisi.org.tr/hikaye\#2-fars-edebiyati (Erişim: 10.04.2019).

Kanar, M. (1999). Çağdaş İran Edebiyatının Doğuşu ve Gelişmesi. İstanbul: Say Yayınları.

Kaplan, M. (2000). Hikâye Tahlilleri. İstanbul: Dergâh Yayınları.

Karataş, T. (2007). Edebiyat Terimleri Sözlüğü. Ankara: Akçă̆ Yayınları.

Korkmaz, R. (2003). Küçürek Öykü Türü ve Örnek Bir Öykü Çözümlemesi Ferit Edgü’nün “Öç”ü. Adam Öykü, (49), 25-30.

Korkmaz, R. Deveci, M. (2017). Türk Edebiyatında Yeni Bir Tür: Küçürek Öykü. Ankara: Akçă̆ Yayınları.

Maḥmûdî, M. (2016). Ḩaneş-i Zen Miḥver-i (Feminîstî) Do Dâstânek Ez Mîtrâ Elyâtî, Mecmû̀ a-yi Makâlehâa-yi Dehomîn Beynelmilel-i Tervî̀-i Zebân ve Edeb-i Fârsî, 363-370. https://www.sid.ir/fa/seminar/ViewPaper. aspx?id=50599 (Erişim: 03.04.2019). 
Moran, B. (2000). Türk Romanına Eleştirel Bir Bakış 1. İstanbul: İletişim Ören, A. (2013). Üstkurgu Kavramı Üzerine Üstkurgusal Karışıklıklar. Zeitschrift für die Welt der Türken Journal of World of Turks, 5(3), 223-237. http://www.dieweltdertuerken.org/index.php/ZfWT/article/view/504/ aoren (Erişim: 20.03.2019).

Özata Dirilikyapan, J. (2010). Kabuğunu Kıran Hikâye Türk Öykücülüğ̈̈nde 1950 Kuşağı. İstanbul: Metis Yayınları.

Rûzbeh, M. (2003). Edebiyyât-i Mu asir-i Îrân (Neșr). (7. Baskı). Tahran: Rûzgâr Yayınları.

Sağlık, Ş. (2014). Hikâye/Anlatı/Yorum. Ankara: Hece Yayınları.

Soysal Eşitti, A. (2016). Julio Cortazar'in Açıklamalarin Yazgısı Adlı Küçürek Öyküsü Üzerine Bir İnceleme. Karadeniz Uluslararası Bilimsel Dergi, 32 (32), 205-209. doi: 10.17498/kdeniz.279284

Şerîfî, M. (2013). Ferheng-i Edebîyât-i Fârsî. (5. Baskı).

Tosun, N. (2007). Aforizmanın Hikâyesi: Kısa Kısa Öykü, Heceöykü, (20), 86-93.

Türk Dili ve Edebiyatı Ansiklopedisi. (1981). Hikâye. (4. Cilt). İstanbul: Dergâh Yayınları.

Yâhaḳkî, M. (2000). Cûybâr-i Leḩ̣eha. Tahran: Câmî Yayınları.

Yazıc1, H. (1998). Hikâye. Diyanet İslam Ansiklopedisi. https:// islamansiklopedisi.org.tr/hikaye\#1 (Erişim: 17.03.2019).

Yıldız, E. (2001). Türk Romanında Postmodernist Açılımlar. İstanbul: İletişim Yayınlar1.

\section{Düzeltme:}

Bir önceki sayımız olan 78.sayıda 23-60. sayfalar arasında yayımlanan "Kısasü'l-Enbiyầ'da Sayı Sistemleri" adlı makalenin yazarı Sümeyra ALAN'ın ORCID bilgisi yanlış girilmiştir, doğrusu 0000-0002-4406-2022 şeklindedir. 